Acta vet. scand. $1984,25,411-418$.

From the Department of Internal Medicine I, Division of Parasitology, Norwegian College of Veterinary Medicine, Oslo, Norway.

\title{
SARCOCYSTIS HARDANGERI AND SARCOCYSTIS RANGI N. SP. FROM THE DOMESTIC REINDEER (RANGIFER TARANDUS) IN NORTHERN NORWAY
}

\author{
By \\ Bjørn Gjerde
}

GJERDE, B.: Sarcocystis hardangeri and Sarcocystis rangi n. sp. from the domestic reindeer (Rangifer tarandus) in northern Norway. Acta vet. scand. 1984, 25, 411-418. - Fresh preparations of microisolated sarcocysts from striated muscle of several domestic reindeer from northern Norway were examined by light microscopy. In cardiac muscle, cysts of $\mathrm{S}$. grueneri were found. In skeletal muscle, cysts of S. rangiferi, S. tarandi and S. tarandivulpes were found in all samples examined. In the abdominal muscles of some reindeer, one or two other types of cysts were found.

Cysts of one type were macroscopic in size, and ovoid to cylindrical in shape. The cysts were surrounded by a 8-12 $\mu \mathrm{m}$ thick layer of fibrous material, and measured $1682 \times 910 \mu \mathrm{m}$. The cysts had relatively few and irregularly distributed, $20-35 \mu \mathrm{m}$ long, and $3-5$ um wide, linguiform cyst wall protrusions, which could only be seen after removal of the fibrous layer. These cysts were classified as cysts of S. hardangeri, a species previously described from wild reindeer in southern Norway.

Cysts of the other type were long and slender, measuring 5460 $12700(8994 \pm 2575) \times 95-280(180 \pm 50) \mu \mathrm{m}$. The cysts had numerous very fine, flexible, hair-like cyst wall protrusions, which were 8-10 $\mu \mathrm{m}$ long and less than $0.5 \mu \mathrm{m}$ thick. These cysts are considered to belong to a new Sarcocystis species of reindeer, for which the name Sarcocystis rangi $n$. sp. is proposed. The reindeer is recorded as the intermediate host for 6 different species of Sarcocystis.

intermediate host; cyst structure; cyst wall structure.

Previously, 4 different species of Sarcocystis have been described from the domestic reindeer in northern Norway (Gjerde $1984 \mathrm{a}$ ), the differentiation between the species being based on the light microscopic structure of isolated sarcocysts in 
fresh preparations. A fifth species, S. hardangeri, has so far only been described from wild reindeer in southern Norway (Gjerde $1984 \mathrm{~b}$ ). In the present paper the first description of S. hardangeri from domestic reindeer in northern Norway is given, and the cysts of a new Sarcocystis species, parasitizing skeletal muscle of reindeer, are described.

\section{MATERIALS AND METHODS}

Fresh muscle tissue (the abdominal muscles and the heart) was obtained from several domestic reindeer slaughtered at abattoirs in Kautokeino and Karasjok in Finnmark county in northern Norway. Samples were collected from carcasses with macroscopically visible sarcocysts in the skeletal musculature. Most of the samples were examined when fresh, but some sampless were stored in a deep-freezer for some time, and examined after thawing.

The muscle tissue was examined for sarcocysts both grossly and under a stereoscopic microscope. Cysts were micro-isolated and further examined under a light microscope as previously described (Gjerde $1984 \mathrm{a}$ ), with minor modifications of the technique being applied to the longer cysts of the new species. In the latter case, a small piece of muscle tissue containing the cyst was cut free with scissors, and placed under the stereoscopic microscope. Most of the muscle fibers surrounding the cyst were then gently pulled away with 2 fine needles, and the cyst further examined under the light microscope as described.

F i g u r e s 1-5. Sarcocystis hardangeri; fresh preparations of cysts. In Figs. 3-5 the fibrous layer of the cysts has been removed.

F i g u r e 1. Ovoid cyst surrounded by a layer of fibrous material. A part of the cyst is protruding through a tear made in the fibrous layer during isolation. $\times 30$.

F i g u re 2. Part of cyst surrounded by its fibrous layer (fl). $\times 250$.

F i g r e 3. Part of cyst. Area of cyst wall with few protrusions (p). The protrusions are lying against the cyst surface. Note smooth cyst wall between the protrusions. $\times 500$.

Figure 4. Part of cyst. Area of cyst wall with relatively many, sloping protrusions. $\times 500$.

Figure 5. Detail of cyst wall. Several linguiform protrusions in a more or less upright position. $\times 1000$. 
Bjørn Gjerde: Sarcocyslis hardangeri and Sarcocystis rangi n. sp. from the domestic reindeer (Rangifer tarandus) in northern Norway.

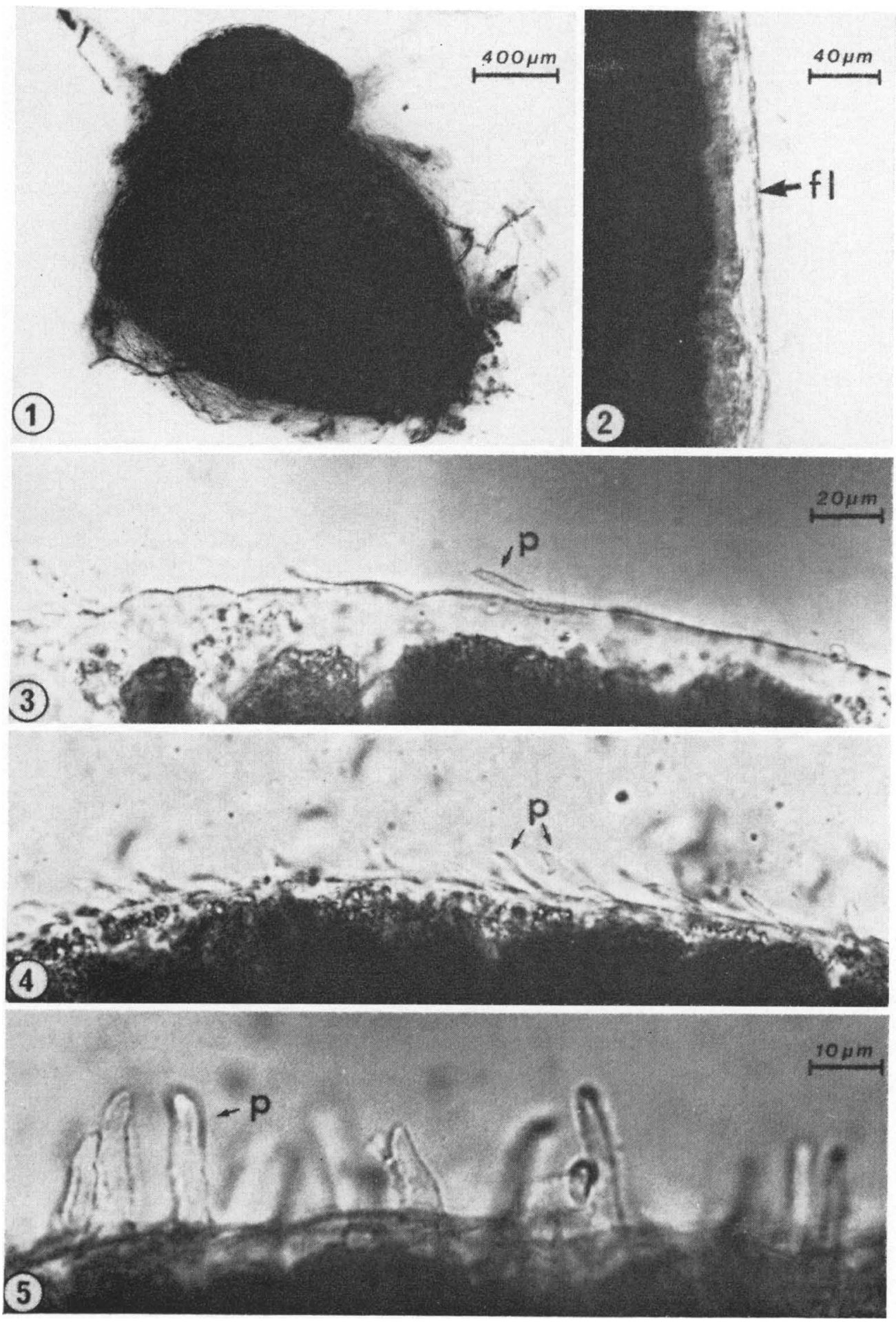




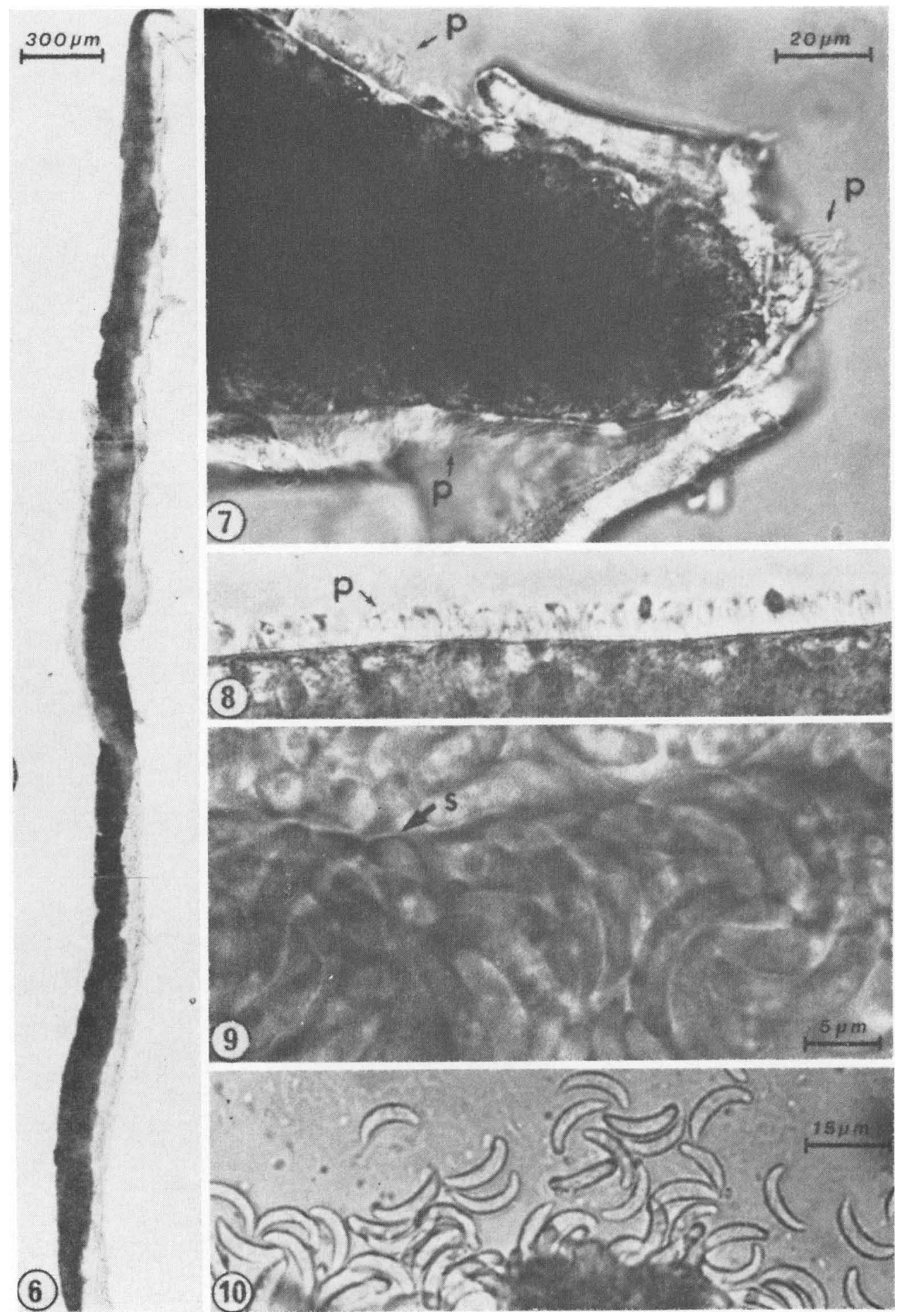




\section{RESULTS}

Deep-freezing seemed to have little effect on the structure of the cyst wall. The cystozoites on the other hand, having been killed by the treatment, were somewhat swollen, and had a more granular interior then the live cystozoites from fresh cysts. Likewise, the compartmentalization of the cyst interior by septa was not as distinct as in fresh cysts. The following descriptions are based mainly on the appearance of fresh cysts and cystozoites.

All animals examined harboured cysts of S. rangiferi, S. tarandi and $S$. tarandivulpes in the skeletal musculature, and cysts of S. grueneri in the cardiac muscle. The cysts of these species have been described in detail previously (Gjerde $1984 \mathrm{a}$ ), and will not be dealt with in this paper. In addition to the species mentioned above, some of the reindeer harboured 1 or 2 types of cysts not previously described from the domestic reindeer.

\section{Infection with Sarcocystis hardangeri}

Relatively few cysts of this species were found in the abdominal muscles. The cysts were usually lying just beneath the muscle fascia, close to the junction of muscle and tendon/aponeurosis. Due to their location they could be somewhat difficult to spot, in spite of their macroscopic size. The cysts were ovoid to cylindrical in shape (Fig. 1), measuring $1682 \pm 430$ (1000$2845) \mu \mathrm{m}$ in length, and $910 \pm 231(605-1300) \mu \mathrm{m}$ in maximum width (diameter); $\mathrm{n}=\mathbf{2 4}$.

The cysts were surrounded by a 8-12 $\mu \mathrm{m}$ thick layer of fibrous material (Fig. 2), the removal of which exposed a cyst wall with relatively few and irregularly distributed cyst wall pro-

Figures 6-1 0. Sarcocystis rangi n. sp.; fresh preparations of cysts and cystozoites.

F i g u r e 6. Long and slender cyst, tapering at both ends. $\times 40$.

Figure 7. Part of cyst. Note very fine, bending, hair-like protrusions $(\mathrm{p}) . \times 680$.

F i g u r e 8. Detail of cyst wall. Note numerous, hair-like protrusions. $\times 680$.

Figure 9. Interior of cyst. Tightly packed cystozoites are lying within two compartments separated by a thin septum (s). $\times 2125$.

F i g u r e 10 . Cystozoites of S. rangi n. sp.. $\times 850$. 
trusions. The sloping, tongue-shaped protrusions were 20-35 بm long, about $2 \mu \mathrm{m}$ thick, and $3-5 \mu \mathrm{m}$ wide with pointed distal ends (Figs. 3-5).

The interior of the cysts was divided into numerous rather small chambers by septa. The chambers lying immediately beneath the cyst surface were filled with banana-shaped cystozoites, measuring $13.0(11.5-14.8) \times 4.3(3.1-5.3) \mu \mathrm{m} ; \mathrm{n}=25$.

Description of the cysts of Sarcocystis rangi n. sp.

In the abdominal muscles of some of the animals examined, cysts different in structure from the cysts of the previously known Sarcocystis species of reindeer, were found. The cysts of the new species could, by careful examination, be seen grossly as very fine, white streaks in the muscles, but were more easily detected under the stereoscopic microscope, i.e. the cysts were micro- to macroscopic in size. The cysts were long and slender, tapering at both ends (Fig. 6). Twenty-three isolated cysts measured $8994 \pm 2575(5460-12700) \mu \mathrm{m}$ in length, and $180 \pm 50$ (95-280) $\mu \mathrm{m}$ in maximum width. Some additional cysts were measured by means of a ruler while still lying in the muscle, their length varying from 5 to $11 \mathrm{~mm}$.

When enclosed by its host cell and neighbouring fibers, the cyst appeared to have a thin cyst wall without protrusions. However, when the cyst wall had been exposed, numerous, very fine, flexible, hair-like protrusions could be seen (Figs. 7 and 8). The protrusions were $8-10 \mu \mathrm{m}$ long and less than $0.5 \mu \mathrm{m}$ thick. The delicate protrusions could be difficult to detect and measure, as they often were more or less bent, or were lying against the surface of the cyst.

The interior of the cysts was divided into numerous small chambers by thin septa (Fig. 9). The chambers were filled with tightly packed banana-shaped cystozoites (Figs. 9 and 10), measuring $14.4 \pm 0.9(12.4-16.5) \times 3.4 \pm 0.5(2.4-4.6) \mu \mathrm{m} ; \mathrm{n}=50$.

\section{DISCUSSION}

The examination of fresh muscle tissue under a stereoscopic microscope as applied in the present and in previous investigations (Gjerde $1984 \mathrm{a}, \mathrm{b}, \mathrm{c}$ ), has proved to be a very useful method for the detection and isolation of sarcocysts. By this method large areas or volumes of tissue may be examined in detail for cysts, 
and those of interest can be isolated and further examined under a light microscope for an immediate species identification. The method may not be as effective, however, when very few cysts are present, or when the cysts are very small, although cysts not longer than $200 \mu \mathrm{m}$ have been detected and isolated by this method. The method also requires that relatively fresh muscle tissue is examined. The change in colour and slimy surface of tissues that have been stored for some time, make both the detection and isolation of the cysts more difficult. However, fresh tissue may be frozen and examined after thawing later, a species differentiation on the basis of the cyst wall structure still being possible after this treatment.

The macroscopic, ovoid to cylindrical cysts surrounded by a fibrous layer found in the present investigation, possessed all the morphological characteristics of $S$. hardangeri described from the wild reindeer in southern Norway previously (Gjerde $1984 \mathrm{~b} \mathrm{c}$ ), and could therefore be classified as this species. The seemingly lower prevalence of this species as compared to the 4 previously known Sarcocystis species of the domestic reindeer, may in part be due to a predilection of this species for other muscle sites than those examined in the present investigation. In the wild reindeer, cysts of S. hardangeri were found to be more numerous in the muscles of the scapula than in the abdominal muscles (Gjerde $1984 \mathrm{c}$ ). However, the prevalence of a given Sarcocystis species is also dependent on the distribution and number of its definitive hosts, and their relationship with the intermediate host.

The structure of the cyst wall of mature cysts is considered to be a reliable criterion for differentiating between different species of Sarcocystis within an intermediate host (Erber 1977, Mehlhorn \& Heydorn 1978). In spite of a strong structural resemblance between sarcocysts from different species of intermediate hosts, the cysts are considered to belong to different Sarcocystis species specific to each intermediate host (Mehlhorn \& Heydorn 1978). However, relatively few cross-infection experiments have been carried out. The new species described in the present paper is, until proven otherwise, considered to be a Sarcocystis species of reindeer, for which the name Sarcocystis rangi n. sp. is proposed. The name is derived from the latin name of the genus to which the domestic reindeer belong. S. rangi 
n. sp. also seems to be less prevalent in the domestic reindeer in northern Norway than the previously known species.

The present investigation has shown that the reindeer may act as intermediate host for 6 different species of Sarcocystis, and that a single animal may harbour such a multiple infection simultaneously. To the author's knowledge, no species of intermediate host has previously been found to be the host of more than 4 species of Sarcocystis (Tadros \& Laarman 1982). The 6 ultrastructurally different types of sarcocysts described from roe deer by Entzeroth (1982), probably represented only 3 or 4 different species.

The differentiation between the mature cysts of the 6 Sarcocystis species infecting the reindeer is based on the size and shape of the cysts, the cyst wall structure and the presence or absence of a fibrous layer around the cysts. The type of tissue invaded may also be useful for an identification of the species, as $\mathrm{S}$. grueneri is the only species normally found in cardiac muscle, and does not seem to parasitize skeletal muscle. S. grueneri is also the only species having no light microscopically visible cyst wall protrusions, while S. rangiferi and S. tarandi both have stable, upright, finger-like protrusions, S. tarandivulpes has very short, knob-like protrusions, $S$. hardangeri has long, sloping, linguiform protrusions, and finally, S. rangi n. sp. has fine, hair-like protrusions. Moreover, S. rangiferi and S. hardangeri both have cysts surrounded by a fibrous layer. The 2 last mentioned species also have macroscopically visible cysts, while the cysts of the other species are not readily seen with the naked eye. The cysts of $S$. rangi $n$. sp. are distinctly longer than those of the other Sarcocystis species of reindeer (Gjerde 1984 a, b, $\mathrm{c}$ and present paper).

Electron microscopic studies, now in progress, of different types of sarcocysts from reindeer, have so far in large measure confirmed the differences in cyst wall structure seen by the light microscope, and referred to above (to be published). As to the life cycle of these species, different Canidae have been found to be the definitive hosts for $S$. grueneri and $S$. tarandivulpes (Gjerde \& Bratberg 1984, Gjerde $1984 \mathrm{c}$ ), while the definitive hosts for the other 4 species still are unknown. Several attempts to infect domestic cats with Sarcocystis-infected muscle tissue from domestic reindeer, have so far failed (Gjerde, unpublished observations). 


\section{ACKNOWLEDGEMENTS}

The author thanks K. Korbi, Kautokeino, and K. Bach-Gansmo, Karasjok, for sampling of the muscle tissue used in this investigation, and I. Catrinius and $\mathrm{H}$. Giltvedt for assistance with the photomicrographs.

\section{REFERENGES}

Entzeroth, R.: A comparative light and electron microscope study of the cysts of Sarcocystis species of roe deer (Capreolus capreolus). Z. Parasitenkd. 1982, 66, 281-292.

Erber, M.: Möglichkeiten des Nachweises und der Differenzierung von zwei Sarcocystis-Arten des Schweines. (Detection and differentiation of two Sarcocystis spp. in pigs). Berl. Münch. tierärztl. Wschr. 1977, 90, 480-482.

Gjerde, B.: A light microscopic comparison of the cysts of four species of Sarcocystis infecting the domestic reindeer (Rangifer tarandus) in northern Norway. Acta vet. scand. 1984 a, 25, 195-204.

Gjerde, B.: Sarcocystis infection in wild reindeer (Rangifer tarandus) from Hardangervidda in southern Norway: With a description of the cysts of Sarcocystis hardangeri n. sp.. Acta vet. scand. $1984 \mathrm{~b}, 25,205-212$.

Gjerde, B.: The fox as definitive host for Sarcocyystis sp. Gjerde, 1984 from skeletal muscle of reindeer (Rangifer tarandus). With a proposal for Sarcocystis tarandivulpes n. sp. as replacement name. Acta vet. scand. $1984 \mathrm{c}, 25,403-410$.

Gjerde, B. \& B. Bratberg: The domestic reindeer (Rangifer tarandus) from northern Norway as intermediate host for three species of Sarcocystis. Acta vet. scand. 1984, 25, 187-194.

Mehlhorn, H. \& A. O. Heydorn: The Sarcosporidia (Protozoa, Sporozoa): Life cycle and fine structure. Adv. Parasitol. 1978, 16, $43-91$.

Tadros, W. \& J. J. Laarman: Current concepts on the biology, evolution and taxonomy of tissue cyst-forming eimeriid coccidia. Adv. Parasitol. 1982, 20, 293-468.

\section{SAMANDRAG}

Sarcocystis hardangeri og Sarcocystis rangi n. sp. frå tamrein (Rangifer tarandus) i Nord-Noreg.

Fersk hjerte- og bukmuskulatur av tamrein frå Finnmark vart unders $\varnothing$ kt makroskopisk og under eit stereomikroskop for sarcocyster. Hos alle dyra fann ein cyster av S. grueneri i hjertemuskulaturen, og cyster av S. rangiferi, S. tarandi og S. tarandivulpes i bukmuskulaturen. Hos nokre av dyra fann ein $i$ tillegg cyster av 1 eller 2 andre arter i bukmuskulaturen.

Den eine arta hadde makroskopiske, eggforma cyster omgjevne av eit fibrillært lag. Cystene målte $1682 \times 910 \mu \mathrm{m}$, og cysteveggen hadde 
relativt få, tungeliknande protrusjonar som låg på skrå langs cysteoverflata. Desse cystene vart klassifiserte som cyster av S. hardangeri, ei art som tidlegare berre har vorte rapportert frå villrein frå Hardangervidda.

Den andre arta hadde lange og granne cyster som målte 8994 (5460 $-12700) \times 180(95-280) \mu \mathrm{m}$. Cystene hadde talrike, 8-10 $\mu \mathrm{m}$ lange og mindre enn $0.5 \mu \mathrm{m}$ tjukke, hårliknande protrusjonar. Dei tunne, b $\varnothing y e l e g e$ protrusjonane låg til dels langs cysteoverflata. Desse cystene vert rekna for å tilhøyra ei ny Sarcocystis art hos rein, som ein har gitt namnet Sarcocystis rangi. Rein kan såleis vera mellomvert for 6 ulike Sarcocystis-arter.

(Received June 8, 1984).

Reprints may be requested from: B. Gjerde, the Norwegian College of Veterinary Medicine, Box 8146, Dep., N-0033 Oslo 1, Norway. 